\title{
Osmotic Dehydration and Hot-Air Drying of Pineapple (Ananas comosus)
}

\author{
Diego F. Tirado*, Kevin J. González-Morelo", Mariano J. Puerta”, Oscar Y. Ahumada\#, \\ Diofanor Acevedo Correa\# \\ * Department of Chemical Engineering, School of Chemistry, Universidad Complutense de Madrid, Av. \\ Complutense s/n, 28020, Madrid, Spain. \\ "ResearchGroupNutrición, Salud y Calidad Alimentaria (NUSCA), Universidad de Cartagena, Av. El \\ Consulado, St. 30 No. 48-152, 130015, Cartagena de Indias, Colombia. \\ Corresponding author: ditirado@ucm.es.
}

\begin{abstract}
The preservation of food by dehydration is the oldest and most common method used by humans and the food processing industry. This research aimed to study the osmotic dehydration and hotair drying of "perolera" pineapple (Ananas comosus) in four sweetening agents. Osmotic solutions (sucrose, glucose, fructose and honey) and their mixtures at a ratio 50/50 (sucrose-fructose, honeyglucose, fructose-glucose and sucrose-honey) in water at concentrations of $40{ }^{\circ} \mathrm{Brix}$ and $50{ }^{\circ} \mathrm{Brix}$ were used. A fruit/syrup ratio $1 / 5$, without agitation was used. Water loss (WL) and weight loss (WR) and solids gain (SG) were studied after treatments with all the osmotic solutions.Glucose and honey caused the most significant WL and WR, being the most effective ones at both concentrations to dry.In the same way, the mixture glucose-fructose was the most effective for WL and WR. Results for SG were entirelydifferent.The optimum concentration was $50{ }^{\circ}$ Brix.A product with $61.16 \%$ humidity on a wet basis was obtained. After hot-air drying, a moisture content of $36.43 \%$ was achieved.
\end{abstract}

Keyword - Kinetics, diffusivity, drying, reductor sugars, pineapple.

\section{INTRODUCTION}

Fruits and vegetables are highly perishable products. Commonly, up to $23 \%$ of the most perishable fruits and vegetables are lost due to physiological microbiological deterioration, water loss, mechanical damage during harvest, packaging, inadequate transportation or handling conditions. These losses are more than $40 \%$ to $50 \%$ in tropical and subtropical regions. In addition to microbiological alteration, physical-chemical changes during the processing and storage of fruits can cause deterioration in their quality, affecting colour, texture, taste, smell and nutritional value[1].

Currently, in the agro-industrial sector, many types of technological preservation processes are used and among the most widely used are dehydration processes, which prove to be an effective technique for achieving stable products with sensorial and nutritional characteristics, making it possible to obtain a product for consumption with a certain similarity to those that are in a fresh state and products that are minimally processed[2]-[5]. In the specific case of fruits, the most recommended preservation methods are osmotic dehydration (OD) and hot-air flow dehydration (HFD). The OD is widely used to partially remove water from plant tissues and obtain a significant increase in their shelf life by immersion in a hypertonic solution [6]. The kinetics of OD processes are generally evaluated in terms of water loss, weight loss and solids gain and depend mainly on the characteristics of the raw material and process conditions, such as composition and concentration of the osmotic solution, temperature, immersion time, agitation level, specific aspects of the food (size and shape) and the ratio food/solution [7], [8]. This research aimedto study the osmotic dehydration kinetics of perolera variety pineapple samples(Ananas comosus)in different sweetening agents and concentration to obtain better results in the process, as well as later apply hot-air drying in order to prolong its shelf life.

\section{MATERIAL AND METHODS}

\section{A. Raw Material}

Perolera variety pineapple (A. comosus), sugar, glucose, fructose and commercial honeywere obtained from a local market in the city of Cartagena de Indias (Colombia).

\section{B. Osmotic dehydration and experimental design}

A completely randomised block experimental design was employed, resulting in four treatments. F1: sucrose, glucose, fructose and honey solutions at $40{ }^{\circ}$ Brix each; F2: sucrose, glucose, fructose and honey solutions at $50{ }^{\circ}$ Brix each; F3: mixtures sucrose-fructose, honey-glucose, fructose-glucose and sucrose-honey solutions in a ratio of 50/50 and $40{ }^{\circ}$ Brix each and F4:mixtures sucrose-fructose, honey-glucose, fructose-glucose and sucrose-honey solutions in a ratio of 50/50 and $40^{\circ}$ Brix each. 
Pineapple samples were taken in duplicate at different osmodehydrating times (30 min, $60 \mathrm{~min}, 90 \mathrm{~min}, 120$ $\mathrm{min}, 180 \mathrm{~min}, 240 \mathrm{~min}, 300 \mathrm{~min}$ and $360 \mathrm{~min}$ ) to evaluate the response variables, weight loss (WR), water loss (WL) and soluble solid gain (SG). After extraction from the osmodehydrating solution, the samples were immediately dried with absorbent paper. The samples were weighed before and after dehydration using an analytical balance with a sensitivity of $0.001 \mathrm{~g}$. The soluble solids were determined in the osmodehydrating solution after removing the pineapple samples and then in a refractometer. The moisture content was first determined at $80{ }^{\circ} \mathrm{C}$ for the first $2 \mathrm{~h}$ and then at $105^{\circ} \mathrm{C}$ until constant weight according to A.O.A.C. 930.10[9]. Experimental measurements were made in duplicate for each osmotic treatment.

The calculations of the parameters of water loss (WL), weight loss (WR) and solids gain (SG) were calculated by adapting the equations of Agnelliet al.,[10], expressed in $\mathrm{g} 100 \mathrm{~g}^{-1}$ of fresh product:

$\mathrm{WL}=\frac{\left(\mathrm{M}_{0} \times \mathrm{H}_{0}\right)-\left(\mathrm{M}_{\mathrm{t}} \times \mathrm{H}_{\mathrm{t}}\right)}{\mathrm{M}_{0}} \times 100$

$\mathrm{WR}=\frac{\left(\mathrm{M}_{0}-\mathrm{M}_{\mathrm{t}}\right)}{\mathrm{M}_{0}} \times 100$

$S G=\frac{\left(M_{t} \times S_{t}\right)-\left(M_{0} \times S_{0}\right)}{M_{0}} \times 100$

where $M_{0}$ is the initial weight of the pulp, $M_{t}$ is the final weight of the pulp, $H_{0}$ is the initial weight of the pulp, $\mathrm{H}_{\mathrm{t}}$ is the final weight of the pulp, $\mathrm{S}_{0}$ is the initial solids of the pulp and $\mathrm{S}_{\mathrm{t}}$ is the final solids of the pulp

\section{Hot-air drying}

A conventional oven was used for the final drying of the product. After finishing the dehydration time, pineapple samples were dried for $4 \mathrm{~h}$ and weighed at intervals of $30 \mathrm{~min}$ until constant weight.

D. Statistical analysis

Statistical analysis was made using the Statgraphicssoftware (Statgraphics Centurion Version 16.1.15, Chicago, EE. UU) with analysis of variance and correlation between variables. The p-value tests the statistical significance of each factor. When this value was less than 0.05 , the variance analysis (ANOVA) indicated that the manipulated factor had a statistically significant influence at a $95 \%$ confidence level on the response variable.

\section{III.RESULTS AND DISCUSSIONS}

\section{A. Weight loss (WR)}

Fig. 1, 2, 3 and 4 show WR at $40^{\circ}$ Brix and $50^{\circ}$ Brix of the osmotic solutions (sucrose, glucose, fructose and honey) and their mixtures. This variable wasmore significant as the concentration of the medium osmotic increased. On the other hand, the solutions that caused the most considerableWRwere those of glucose and honey at both concentrations used. In the same way, the mixture glucose-fructosewas the only mixture that had significant values by using both concentrations. However, without presenting synergy, and such as the others, theyshowed antagonism.

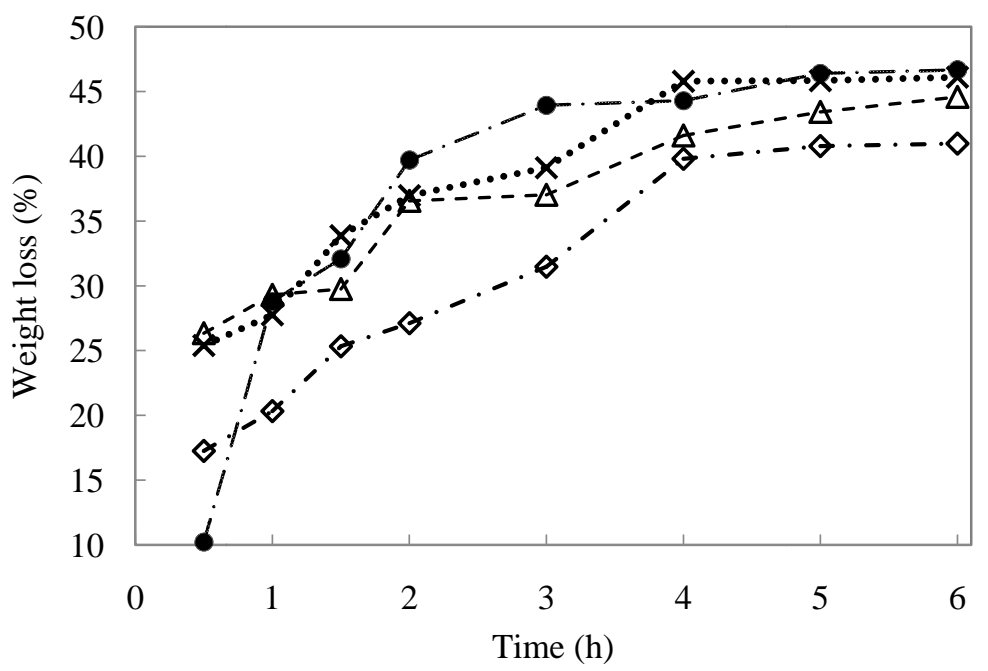

Fig. 1.Weight loss at $40^{\circ}$ Brix by using sucrose $(-\infty \cdot)$, glucose $(-\bullet-)$, fructose $(--\bullet-)$ and honey $(\cdots \times \cdots)$. 


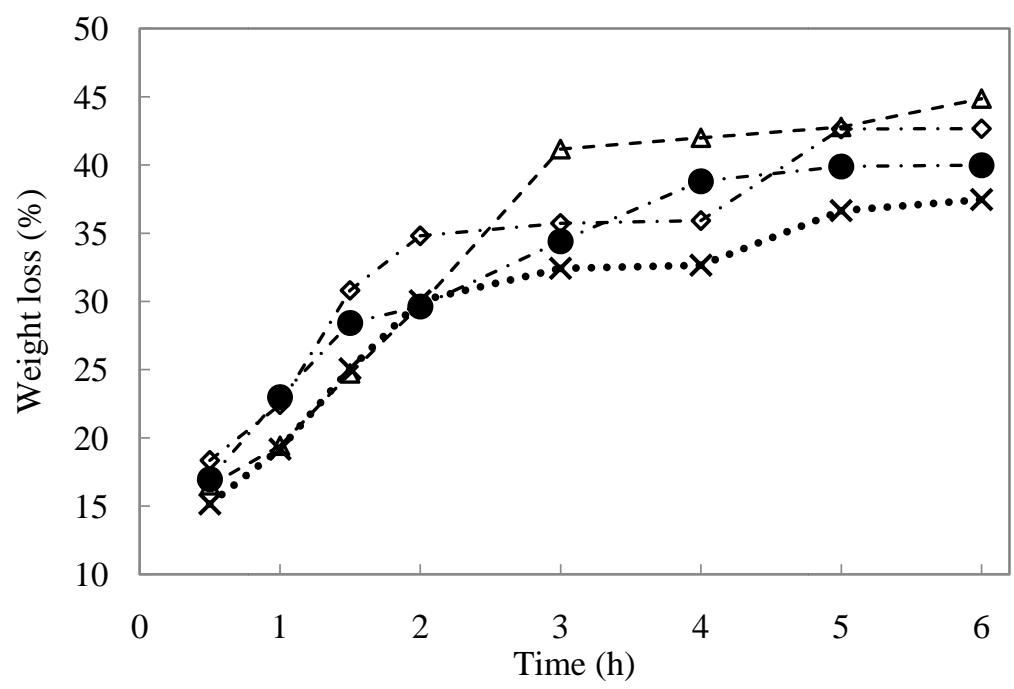

Fig. 2. Weight loss at $40^{\circ}$ Brix by using the mixtures sucrose-fructose $(-\infty \cdot)$, honey-glucose $(-\bullet-\cdot)$, fructose-glucose $\left(--\bullet^{-}\right)$and sucrose-honey $(\cdots \times \cdots \cdot)$

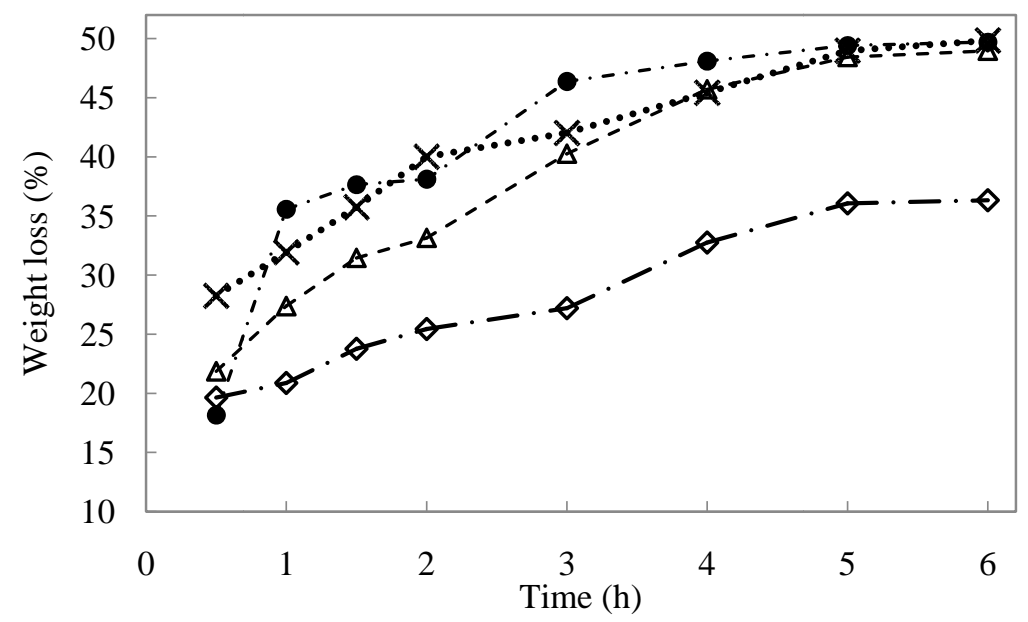

Fig. 3. Weight loss at $50^{\circ}$ Brix by using sucrose $(-\diamond \cdot)$, glucose $(-\bullet-\cdot)$, fructose $\left(---^{-}\right)$and honey $(\searrow)$.

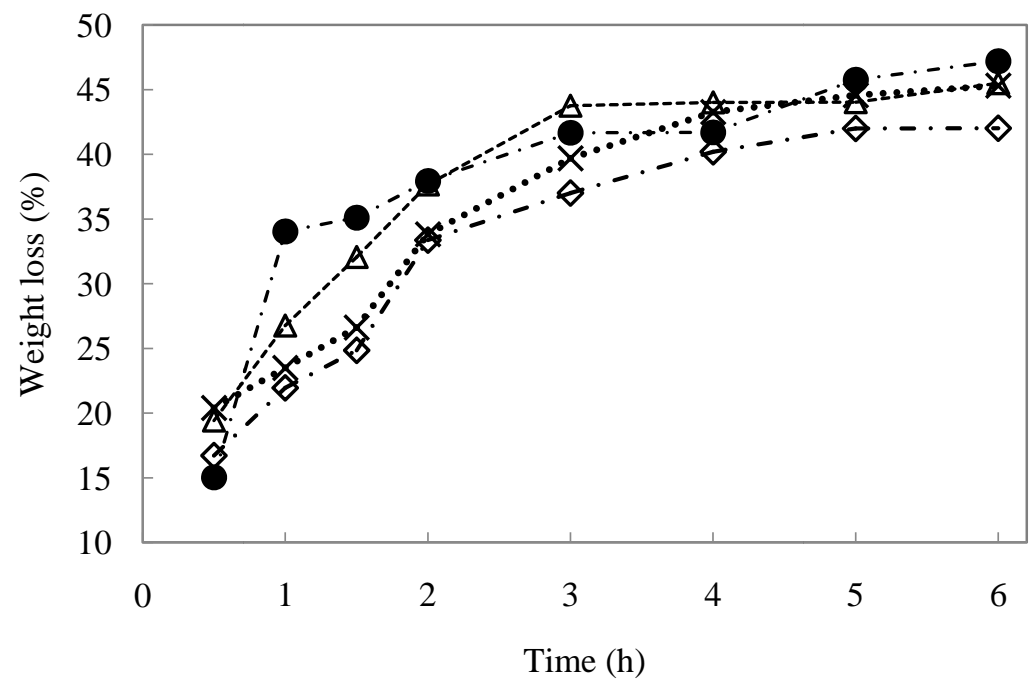

Fig. 4.Weight loss at $50^{\circ}$ Brix by using the mixtures sucrose-fructose $(-\infty \cdot)$, honey-glucose $(-\bullet-\cdot)$, fructose-glucose $(--\Delta-)$ and sucrose-honey $(\cdots \times \cdots)$. 
In addition, Fig. 1, 2, 3 and 4 indicated a more significant WR during the first $5 \mathrm{~h}$ and therefore an increase in the elimination of water from the fruit, suggesting that the speed of dehydration was more pronounced in the range between the first $4 \mathrm{~h}$ and $5 \mathrm{~h}$ of the process, which was in agreement with those results reported by Barbosa and Vega[11], who concluded that the higher WRduring the osmotic drying process of fruits occurs in the first $5 \mathrm{~h}$, being the initial $2 \mathrm{~h}$ the highest mass removal rate. This kinetic trend was also reported by Ríos et al.,[12] in the osmodehydration of Hawaiian papaya (Carica papaya) using four sweetening agents: bee honey, cane honey, bee honey cream and sucrose.

As a conclusion, glucose and honey were the most effective in less than $6 \mathrm{~h}$, taking into account that these molecules do not have such a high molecular weight, which allowed it to remove much of the mass without forming a crust around the pineapple slice.

\section{B. Water loss (WL)}

The most significant changes in WL occurred during the first $4 \mathrm{~h}$ of the osmotic dehydration process (Fig. 5, 67 and 8). This kinetics of osmotic dehydration was similar to those published by several researchers[13]-[17]. The higher rates of WL in the tests carried out were presented at the beginning of the process, as a consequence of a higher osmotic dehydration force existing between the food and the hypertonic solution as it was reported by Salvatoriet al., [18]. Moreira and Xidieh[19] explained that the increase in the concentration of the osmotic solution helps the WL due to the higher osmotic pressure gradient in the product/solution interface, giving a higher speed of mass transfer. These results were consistent with those reported by Della Roca \&Mascheroni[20].

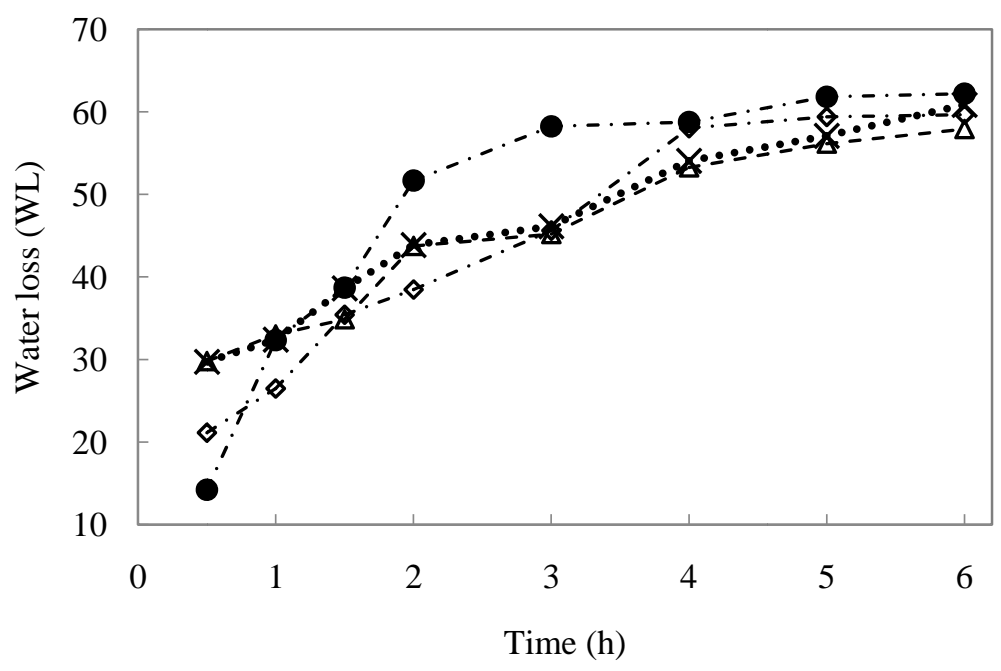

Fig. 5. Water loss at $40^{\circ}$ Brix by using sucrose $(-\diamond \cdot)$, glucose $(-\bullet-\cdot)$, fructose $(--\Delta-)$ and honey $(\cdots \times \cdots \cdot)$.

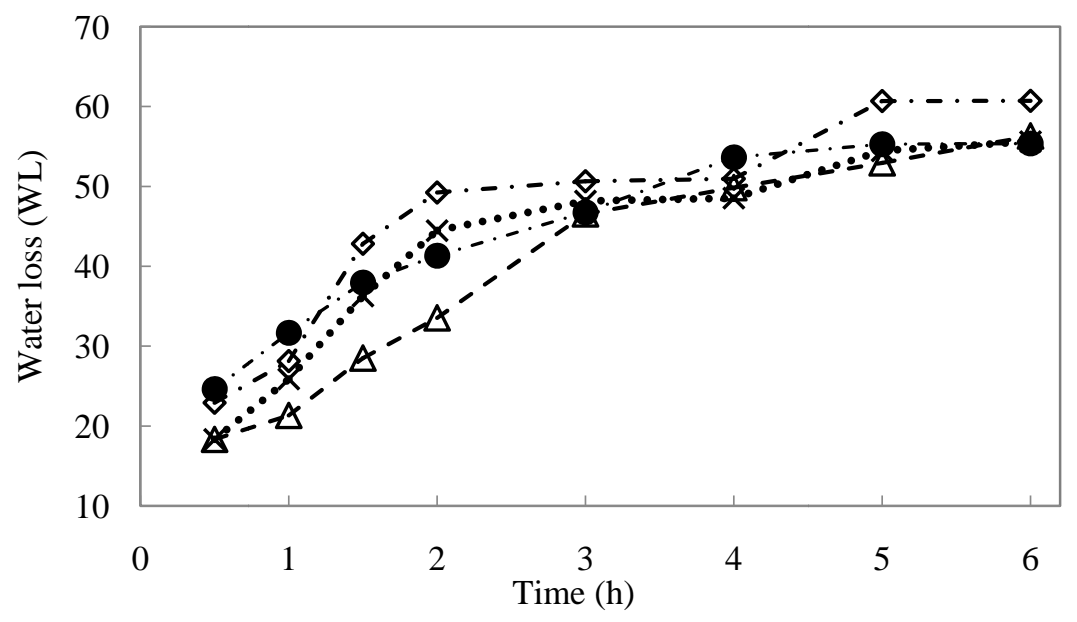

Fig. 6.Water loss at $40^{\circ}$ Brixby using the mixtures sucrose-fructose $(-\infty \cdot)$, honey-glucose $(-\bullet-\cdot)$, fructose-glucose $(--\bullet-)$ ) and sucrosehoney $(\cdots \times \cdots)$ 


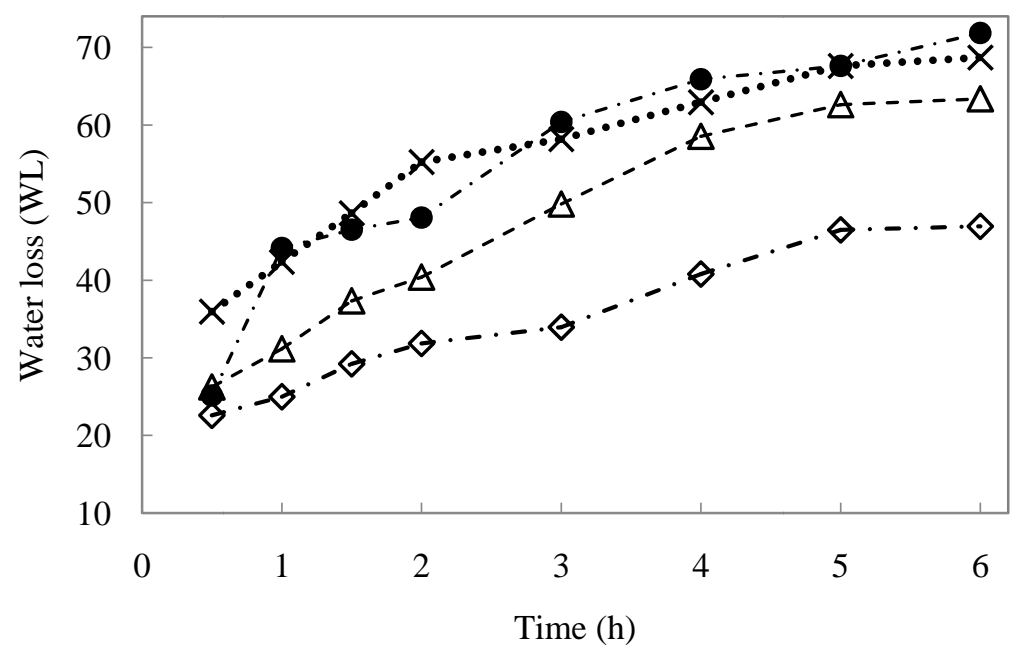

Fig. 7.Water loss at $50{ }^{\circ}$ Brix by using sucrose $(-\diamond \cdot)$, glucose $(-\bullet-\cdot)$, fructose $(--\bullet-)$ and honey $(\cdots \times \cdots)$.

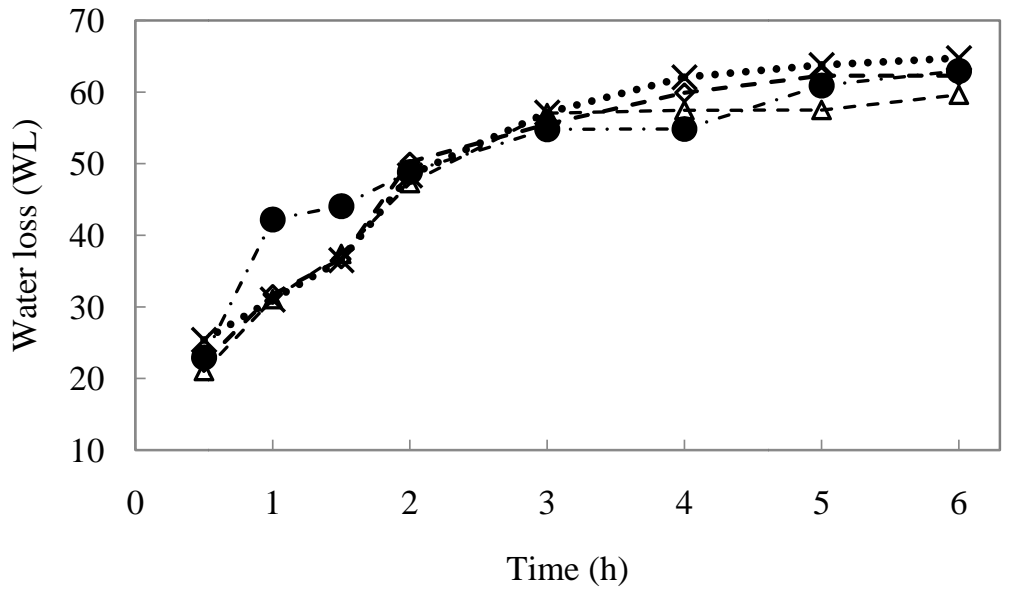

Fig. 8. Water loss at $50^{\circ}$ Brixby using the mixturessucrose-fructose $(-\infty \cdot)$, honey-glucose $(-\bullet-\cdot)$, fructose-glucose $(--\bullet-)$ and sucrosehoney $(\cdots \times \cdots)$.

In general, the solutions that showed the most significant water losses were individually those of glucose and honey in both concentrations, accompanied by the mixture of glucose-fructose, which was the only mixtures that had substantial values, but without presenting synergy, and again, such as the others, theyoffered antagonism.That abovecoincided with the phenomenon of WR, according to what has been reported by Della Rocca and Mascheroni[20], who stated that the phenomenon of WR corresponds to a more significant WL, and therefore a lower concentration of soluble solids in the solution.

Moreira and Xidieh[19], who obtained similar results, indicated that the choice of a high concentration of the medium brings some benefits regarding faster WL. However, a much higher SG is achieved. In general, the highest rates of dehydration were reached between $4 \mathrm{~h}$ and $5 \mathrm{~h}$ of processing, which could be taken into account when applying a fruit osmotic dehydration processes.

In Fig. 5, 6, 7 and 8, it could be seen that there was a significant change in the WL for the different concentrations depending on the time, and it was greater for those of higher concentration. Studies reported by Fernándeset al.,[21] about osmotic dehydration of papaya demonstrated that an increasing the concentration of sucrose in the osmotic solution led to a more significantWL from the fruits towards the osmotic solution. The influence of osmotic solution on effective mass transfer is stronger than the influence of temperature on the process. As the concentration of the solute increases, it can be observed that the osmotic pressure of the solution increases and with this WL, i.e. dehydration prevails, although the rate of solids transfer remains lower [22]. Figures show that $\mathrm{WL}$ at $50^{\circ}$ Brix according to the process time in which the most significant loss of water was reached in the first $2 \mathrm{~h}$ corresponded to glucose, being evident its action until the end of the process, followed by honey. 
In the first hour,WL was more significantup to $20 \%$ for the mixture honey-glucose unlike the mixture fructose-glucose that only at the same time reached $20 \% \mathrm{WL}$. That abovewas due to the osmodehydrating power, which is greater if the molecular weight of the compound is lower and its ionising capacity is high. Depending on the chemical nature of the compounds used to prepare the syrup, i. e. its composition, they will exert a different osmotic pressure. Some authors express this osmotic force regarding osmosity, a term which shows the number of moles of sodium chloride per litre needed to obtain a solution with the same osmotic pressure of the solution under study[1].

For honey, there were no significant differences in soluble solids concentrations of $40{ }^{\circ} \mathrm{Brix}$ and $50{ }^{\circ} \mathrm{Brix}$, but when comparing this Figure with WL in sucrose solution, it was observed that the osmodehydrating power was much higher, causing a more significantWL.

Fig. 7 and 8 relate WLby using mixtures. It was observed the synergy that the sucrose-fructose mix had, reaching higher percentages of water both in the first $2 \mathrm{~h}$ and at the end of the process, where a high molecular weight with a high sweetening power was added.

All treatments showed a proportional behaviour during the first 2 hregarding WL at $50{ }^{\circ}$ Brix. After 6 h, the glucose followed by honey reached the greatest WL, being the least sucrose treatment, this due to the high molecular weight that caused a crust to the product preventing the flow of water. There was no appreciable difference in any treatment since all present similar behaviours. However, the treatment that stands out from the $3 \mathrm{~h}$ and maintained until 6 hwas the mixture sucrose-honey, due in part to the effect of the ionic power of honey.

\section{Solid gain (SG)}

Fig. 9, 10, 11 and 12 show an increase in SG with increased concentration of the osmodehydrating solution. Close to 6 hof the process a state of quasi-equilibrium was reached, where SG remained the same until the osmodehydration was finished.

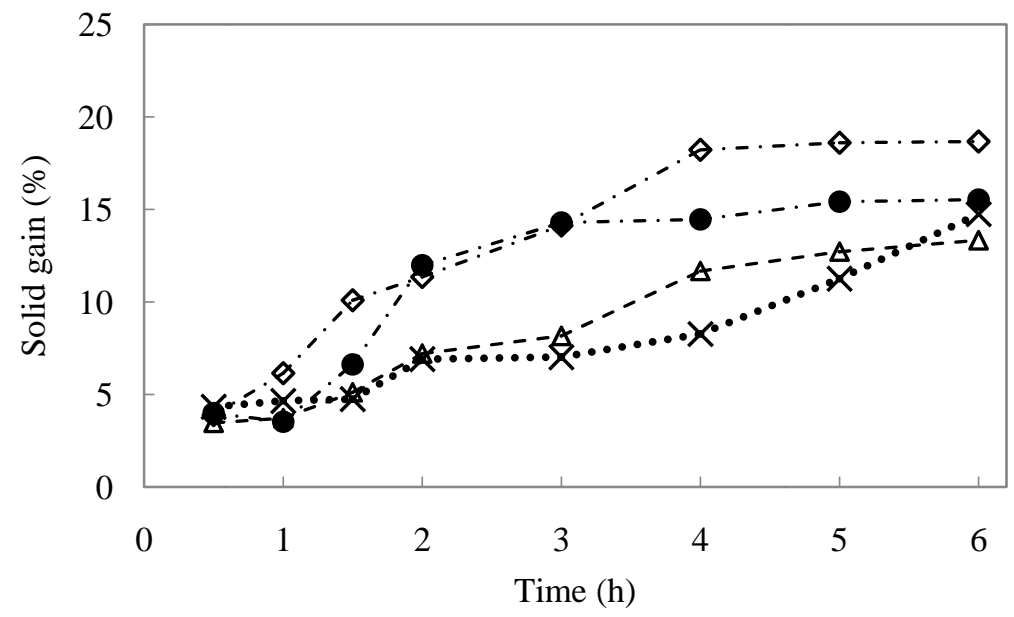

Fig. 9.Solid gain at $40^{\circ}$ Brix by using sucrose $(-\diamond \cdot)$, glucose $(-\bullet-)$, fructose $(--\Delta-)$ and honey $(\cdots \times \cdots)$.

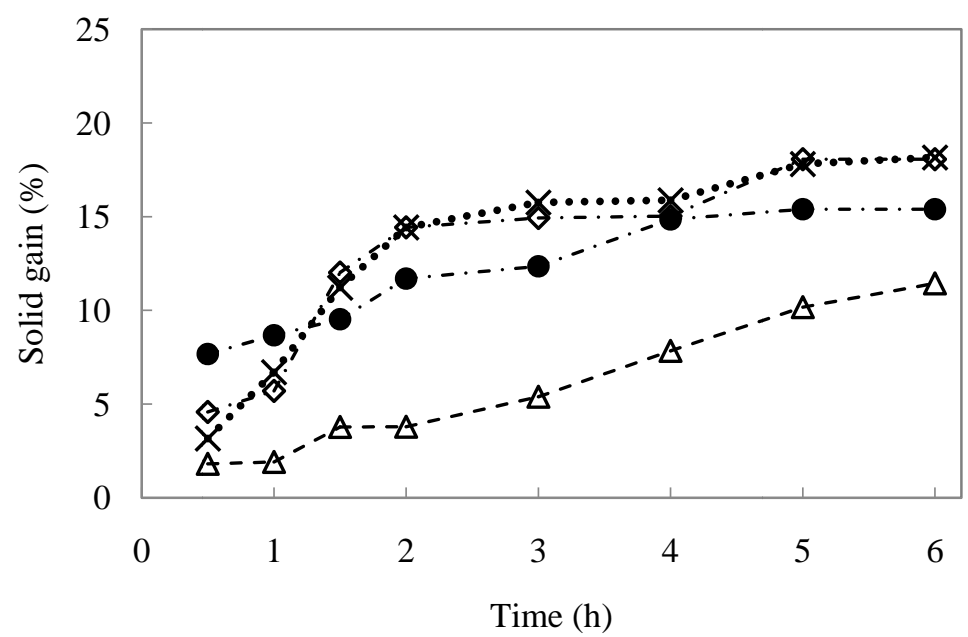

Fig. 10.Solid gain at $40^{\circ}$ Brixby using the mixtures sucrose-fructose $(-\infty \cdot)$, honey-glucose $(-\bullet-\cdot)$, fructose-glucose $(--\bullet-)$ and sucrosehoney $(\cdots \times \cdots)$. 


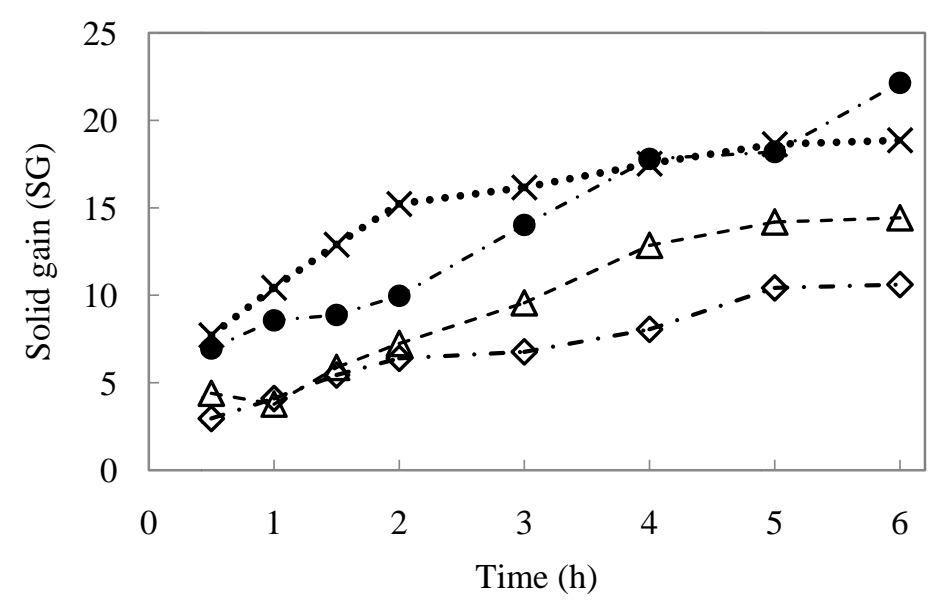

Fig. 11.Solid gain at $50^{\circ}$ Brix by using sucrose $(-\infty \cdot)$, glucose $(-\bullet-)$, fructose $(--\bullet-)$ and honey $(\cdots \times \cdots)$.

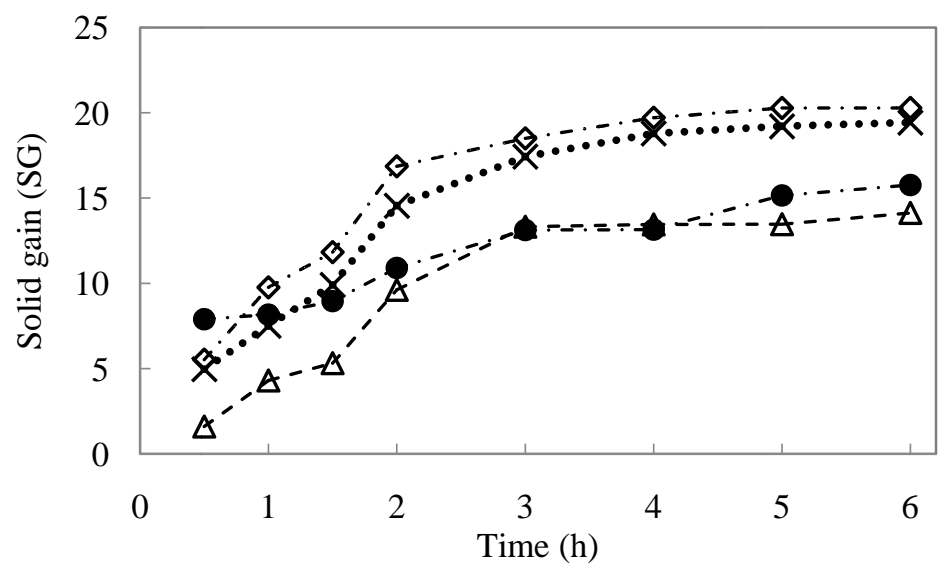

Fig. 12.Solid gain at $50^{\circ}$ Brix by using the mixtures sucrose-fructose $(-\infty \cdot)$, honey-glucose $(-\bullet-\cdot)$, fructose-glucose $\left(---^{-}\right)$and sucrosehoney $(\cdots \times \cdots)$.

A simple difference in SG velocity can be seenin the first $3 \mathrm{~h}$ in Fig. 10 and 11 (at $50^{\circ} \mathrm{Brix}$ ). This was due to the slightly higher concentration,which generated higher SG due to the higher osmotic pressure caused by this concentration. Also, according to García-Pereira et al.,[23] when the mass of the fruit begins to experience a slight increase, the entrance speed of the solute is higher during the first $2 \mathrm{~h}$, and it is higher than that of the wateruntil the process is stabilised and dehydration begins.

It was observed that at a higher concentration of soluble solids, there wasa more significant SG due to the osmotic pressure exerted by the sweetening agent on the pineapple membrane, this parameter was directly linked to the concentration in which the solution was found.

When comparing these results with those obtained by Garcia-Pereiraet al.,[23] it can be seen that during the first hours of the process occurred the highest SG, since according to its conclusions this process goes through the first stage of osmosis where there is an exchange of solutes between the solution and the food, and it is precisely there when the fruit mass begins to experience a slight increase as the velocity of the solute's entrance during the first $2 \mathrm{~h}$ is higher than that of the water outlet, until the process is stabilised and dehydration begins.

As can be seen, the products presented an increase in soluble solids content. This increase was due to the gain of osmotic solution during the process. In relation to hot-air drying, the increase in soluble solids content was due to the reduction of the water content in the fruit. The greater the reduction of water in the product, the higher the soluble solids content.WL and SG increase as the concentration of the osmotic solution and temperature increases[1].

\section{Hot-air drying}

Fig. 13 and 14 show the pineapple drying curves after the application of the osmodehydration processes with the individual solutions and their mixtures, respectively.In Fig. 13 and 14 can be seen that the pineapple sample achieved a percentage of weight loss close to $100 \%$ after $1.5 \mathrm{~h}$ of drying. The fact of obtaining such a high percentage shows the degree to which the pineapple was dried by removing the maximum amount of water possible. 


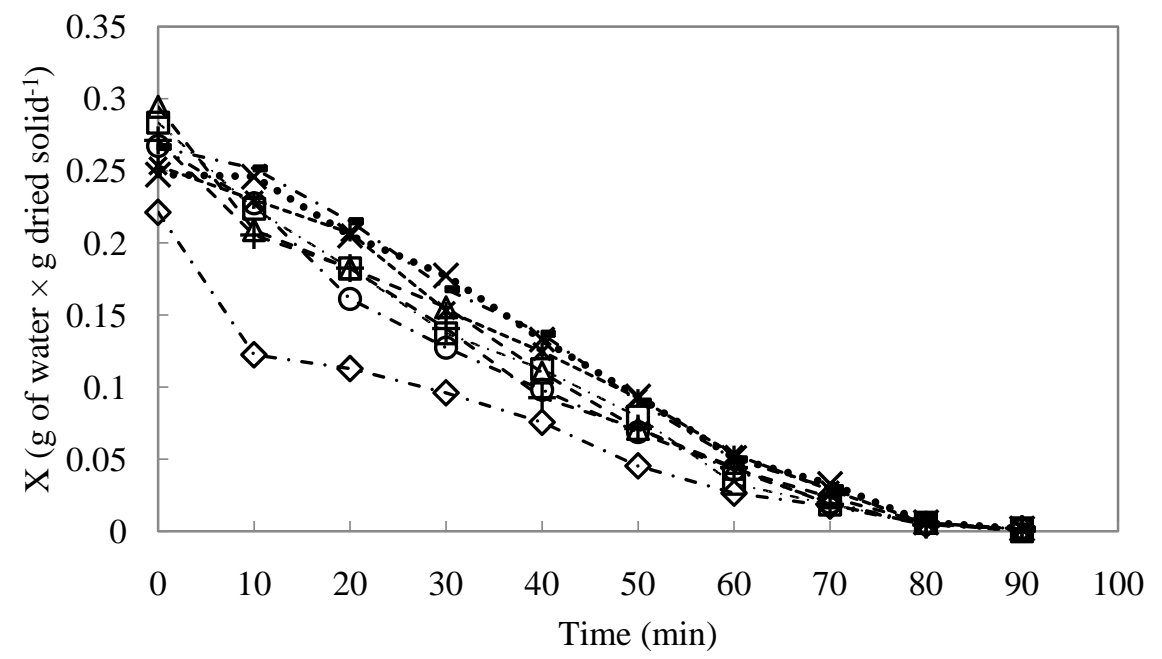

Fig. 13.Drying curves of samples after osmodehydrationby using sucrose at $40^{\circ} \mathrm{Brix}\left(\boldsymbol{-}^{-} \bullet-\right)$, glucose at $40^{\circ} \mathrm{Brix}\left(\left(^{-} \square \cdot \cdot\right)\right.$, fructose at

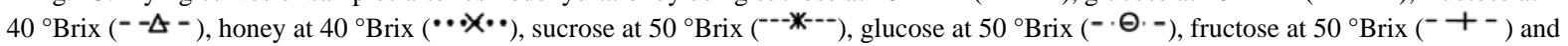
honey at $50^{\circ}$ Brix $(-\cdots)$.

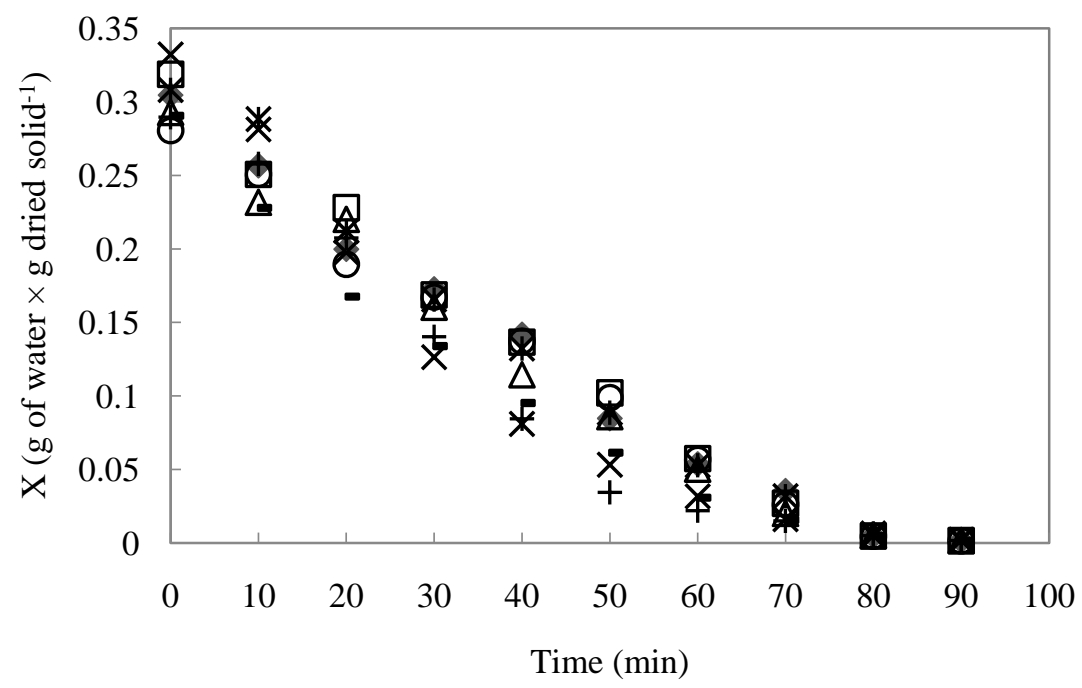

Fig. 14.Drying curves of samples after osmodehydrationby using the mixtures sucrose-fructose at $40^{\circ}$ Brix $(-\cdot \bullet \cdot-)$, honey-glucose at

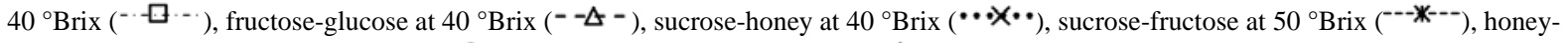

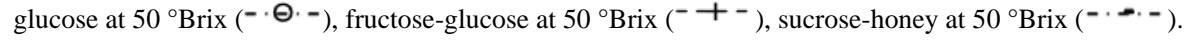

In dehydration and hot-air drying processes, the mass decreases as the time of the process increases, but in the case of OD, this method undergoes the first stage of osmosis as previously indicated where solutes are exchanged between the solution and the food. It is precisely there when the fruit mass begins to experience a slight increase since the velocity of the solute's entrance during the first two hours is higher than that of the water outlet until the process is stabilised and dehydration begins[1].

In the case of HFD as shown in Fig. 13 and 14, the mass always tends to decrease, experiencing most significant loss in the course of the process, so it is in this interval of time where drying has a higher incidence on the fruit, also coinciding with results obtained by Zapata and Castro [24] who argued that in this interval of time was where the most considerable loss of mass occurs in dehydrated fruit by this method. Afterwards, the fruit begins to experience a tendency to maintain its weight constant or practically unchanged.

From Fig. 13 it can be seen that all the treatments were carried out until an optimal drying (almost 100\%), but it was also observed that there were differences among them, specifically regarding drying time. For example, the osmotic treatment that reduced water loss in greater proportion was fructose at $40{ }^{\circ} \mathrm{Brix}$, since it was the treatment that reached a maximum drying time after $2 \mathrm{~h}$. This was mainly because fructose has a high osmosity index in relation to other compounds. This osmosity is greater for fructose since its molecular weight is lower and its ionising capacity is higher. Fig. 14 showed better results with the mixture glucose-fructose with a concentration reaching a constant massat $2.5 \mathrm{~h}$. 


\section{E. Statistical analysis of osmotic solutions}

The ANOVA results showed that the type of osmotic solution, concentration and time, all with a p-value lower than 0.01 were highly significant for WR, WL and SGduring osmodehydration of pineapple (Table 1).For a better analysis of the process and experimental design, interactions were made between the factorstype of osmotic solution (A), concentration (B) and time (C), and it was observed that the $\mathrm{AB}, \mathrm{AC}$ and $\mathrm{BC}$ interactions had a highly significant difference with p-values. This meant that WR, WL and SG during the process were influenced by the type of osmotic solution, concentration, time and its interactions. That is, the process wascontrolled by the kind of osmotic solution, concentration, time and its interactions.

Table 1.Analysis of varianceof variables of the process

\begin{tabular}{lcccccc}
\multirow{2}{*}{ Effect } & \multicolumn{2}{c}{ Weight loss } & \multicolumn{2}{c}{ Water loss } & \multicolumn{2}{c}{ Solid gain } \\
\cline { 2 - 7 } & F-test & p-value & F-test & p-value & F-test & p-value \\
\hline $\begin{array}{l}\text { A: Osmotic } \\
\text { solution }\end{array}$ & 15640.11 & 0.0000 & 834.53 & 0.0000 & 586.22 & 0.0000 \\
B: Concentration & 1665.13 & 0.0000 & 364.91 & 0.0000 & 76.35 & 0.0000 \\
C: Time & 39475.89 & 0.0000 & 8350.39 & 0.0000 & 1663.10 & 0.0000 \\
AB & 102.88 & 0.0000 & 22.81 & 0.0000 & 5.00 & 0.0178 \\
AC & 1113.98 & 0.0000 & 224.48 & 0.0000 & 42.81 & 0.0000 \\
BC & 8.12 & 0.0021 & 7.63 & 0.0027 & 7.21 & 0.0034 \\
\hline
\end{tabular}

\section{CONCLUSIONS}

It could be concluded that the product obtained good results in the preservation through osmotic dehydration highlighting the solutions with glucose and honey and mixtures of glucose-fructose that caused more dehydration in the concentrations established. On the other hand, hot-air drying provided complete dehydration of the product, possibly allowing for a prolonged shelf life. Static analyses confirmed that there was a strong influence of the type of osmotic solution, operating time and concentration on weight loss, water loss, and solids gain. It is expected through this research to support the industrial sector, which embraces this technology as a means of production.

\section{REFERENCES}

[1] D. Acevedo, D. F. Tirado, and L. E. Guzmán, "Deshidratación osmótica de pulpa de tamarindo (Tamarindus indica L.): influencia de la temperatura y la concentración,” Revista U.D.C.A Actualidad \& Divulgación Científica, vol. 17, no. 1, pp. 123-130, 2014.

[2] D. F. Tirado, D. Acevedo, and P. M. Montero, "Heat and Mass Transfer during Frying of Food: Tilapia (Oreochromis niloticus) and Pan fruit (Artocarpus communis),” Información tecnológica, vol. 26, no. 1, pp. 85-94, 2015.

[3] D. F. Tirado, D. Acevedo-correa, and P. M. Montero-castillo, "Dried fruit breadfruit slices by Refractive Window TM technique," Tecno Lógicas, vol. 19, no. 36, pp. 103-111, 2016.

[4] D. F. Tirado, D. Acevedo, and L. E. Guzmán, "Coeficientes convectivos de transferencia de calor durante el freído de láminas de tilapia (Oreochromis niloticus),” Información tecnológica, vol. 24, pp. 41-46, 2013.

[5] D. F. Tirado, D. Acevedo Correa, and P. M. Montero Castillo, "Drying of arenca (Triportheus magdalenae): influence of salting on dried and wet stack,” Biotecnoloía en el Sector Agropecuario y Agroindustrial, vol. 14, no. 2, p. 57, 2016.

[6] A. Cataldo, G. Cannazza, E. De Benedetto, C. Severini, and A. Derossi, "An alternative method for the industrial monitoring of osmotic solution during dehydration of fruit and vegetables: A test-case for tomatoes,” Journal of Food Engineering, vol. 105, no. 1, pp. 186-192, Jul. 2011.

[7] E. K. Dermesonlouoglou, S. Pourgouri, and P. S. Taoukis, "Kinetic study of the effect of the osmotic dehydration pre-treatment to the shelf life of frozen cucumber,” Innovative Food Science \& Emerging Technologies, vol. 9, no. 4, pp. 542-549, Oct. 2008.

[8] E. K. Dermesonlouoglou, M. C. Giannakourou, and P. Taoukis, "Stability of dehydrofrozen tomatoes pretreated with alternative osmotic solutes,” Journal of Food Engineering, vol. 78, no. 1, pp. 272-280, 2007.

[9] AOAC., "Association of Official Analytical Chemistry. Method of Analysis. 18th edition, 1792. Station,.” Washington DC., 2005.

[10] M. E. Agnelli, C. M. Marani, and R. H. Mascheroni, "Modelling of heat and mass transfer during (osmo) dehydrofreezing of fruits," Journal of Food Engineering, vol. 69, no. 4, pp. 415-424, 2005.

[11] G. V Barbosa-Canovas and H. Vega-Mercado, Deshidratación de alimentos. Acribia, 2000.

[12] M. M. Rios Perez, C. J. Marquez Cardozo, and H. J. Ciro Velasquez, "Osmotic dehydration of hawaiian papaya fruits (Carica papaya L.) using four sweetener agents,” Revista Facultad Nacional de Agronomía, Medellín, vol. 58, no. 2, pp. 2998-3002, 2005.

[13] H. Kowalska and A. Lenart, "Mass exchange during osmotic pretreatment of vegetables," Journal of Food Engineering, vol. 49, no. 23, pp. 137-140, 2001.

[14] E. Spiazzi and R. Mascheroni, "Mass transfer model for osmotic dehydration of fruits and vegetables-I. Development of the simulation model,” Journal of Food Engineering, vol. 34, no. 4, pp. 387-410, 1997.

[15] H. N. Lazarides, E. Katsanidis, and A. Nickolaidis, "Mass transfer kinetics during osmotic preconcentration aiming at minimal solid uptake,” Journal of Food Engineering, vol. 25, no. 2, pp. 151-166, 1995.

[16] E. Palou, A. López-Malo, A. Argaiz, and J. Welti, "The use of peleg’s equation to model osmotic concentration of papaya," Drying Technology, vol. 12, no. 4, pp. 965-978, 1994.

[17] K. J. Park, A. Bin, F. P. Reis Brod, and T. H. K. Brandini Park, “Osmotic dehydration kinetics of pear D’anjou (Pyrus communis L.),” Journal of Food Engineering, vol. 52, no. 3, pp. 293-298, May 2002.

[18] D. Salvatori, A. Andrés, A. Chiralt, and P. Fito, "Osmotic dehydration progression in apple tissue I: spatial distribution of solutes and moisture content,” Journal of Food Engineering, vol. 42, no. 3, pp. 125-132, Nov. 1999.

[19] P. Moreira and F. Elizabeth Xidieh Murr, "Mass transfer kinetics of osmotic dehydration of cherry tomato," Journal of Food Engineering, vol. 61, no. 3, pp. 291-295, Feb. 2004. 
[20] P. Della Rocca and R. Mascheroni, “Deshidratación de papas por métodos combinados de secado: deshidratación osmótica, secado por microondas y convección con aire caliente,” Proyecciones, vol. 9, no. 2, pp. 11-26, 2011.

[21] F. A. N. Fernandes, S. Rodrigues, O. C. P. Gaspareto, and E. L. Oliveira, "Optimization of osmotic dehydration of papaya followed by air-drying,” Food Research International, vol. 39, no. 4, pp. 492-498, May 2006.

[22] S. I. Arreola and M. E. Rosas, “Aplicación de Vacío en la Deshidratación Osmótica de Higos (ficus carica),” Información tecnológica, vol. 18, no. 2, 2007.

[23] A. García-Pereira, S. Muñiz-Becerá, A. Hernandez Gomez, and L. González, “Análisis comparativo de la cinética de deshidratación Osmótica y por Flujo de Aire Caliente de la Piña (Ananas Comosus, variedad Cayena lisa),” Revista Ciencias Técnicas Agropecuarias, vol. 22, no. 1, pp. 62-69, 2013.

[24] J. Zapata and G. Castro, “Cinética de la Deshidratación Osmótica de Piña con Alcohol Etílico como Osmodeshidratante,” Revista de la Facultad de Ingeniería, vol. 11, no. 1, pp. 7-19, 1999.

\section{AUTHOR PROFILE}

Diego F. Tirado is a doctorate student in Chemical Engineering at the Universidad Complutense de Madrid (Spain). Mr. Tirado has a bachelor degree in Food Engineering and a master degree in Environmental Engineering from the Universidad de Cartagena (Colombia).

Kevin José González Morelo works as research assistant in the Research Group Nutrición, Salud y Calidad Alimentaria (NUSCA) of the University of Cartagena (Colombia). Mr. González-Morelo completed his undergraduate in Food Engineering at the University of Cartagena.

Diofanor Acevedo Correa works as full-time professor at the University of Cartagena (Colombia). Dr. Acevedo completed his doctorate at the University of Valle (Cali-Colombia). Mr. Acevedo completed his undergraduate in Food Engineering and Pharmaceutical Chemistry at the University of Cartagena.

Mariano J. Puerta works as research assistant in the Research Group NUSCA. Mr. Peña completed his undergraduate in Food Engineering at the University of Cartagena.

Oscar Y. Ahumada works as research assistant in the Research Group NUSCA. Mr. Bohórquez completed his undergraduate in Food Engineering at the University of Cartagena. 